\title{
MORPHOMETRIC CHARACTERIZATION OF THE SEEDS AND GERMINATION OF SIX ENDEMIC LAMIACEAE SPECIES IN NORTHEASTERN BRAZIL
}

\author{
Natália dos Santos Barroso ${ }^{1}$, Cíntia Luiza Mascarenhas de Souza ${ }^{1}$, Ariana Reis Messias Fernandes de \\ Oliveira $^{2}$, Marisol Ferraz ${ }^{1}$, Claudineia Regina Pelacani Cruz $^{1}$, Lenaldo Muniz de Oliveira ${ }^{1}$
}

\footnotetext{
${ }^{1}$ Universidade Estadual de Feira de Santana. E-mail: nataliasbarroso@yahoo.com.br; timluiza@ gmail.com; marisolferraz@terra.com.br; claudineiapelacani@gmail.com; lenaldo.uefs@gmail.com

${ }^{2}$ Instituto Federal de Educação, Ciência e Tecnologia Baiano. E-mail: rylreis@gmail.com
}

\section{ABSTRACT}

This research aimed at evaluating the morphometric characteristics of the seeds, germination and initial growth of seedlings of six species of the Lamiaceae family, all endemic of the semiarid region in northeastern Brazil and still poorly studied. One obtained the weight, length, width and moisture content of the seeds of Martianthus leucocephalus, Hyptis suaveolens, H. macrostachys, $H$. platanifolia, Eplingiella fruticosa, and E. cuniloides. The effects of temperature on germination and initial growth of seedling of the three Hyptis species were compared. Seeds showed great variability, and some characteristics can be used to identify the endemic species. Martianthus leucocephalus seeds had the lowest average to length and width, while the highest means were observed in $H$. suaveolens seeds. Temperatures between 25 and $30^{\circ} \mathrm{C}$ provide the highest rate germination and more vigorous seedling establishment. Among the studied species, seeds of $H$. suaveolens showed higher thermal tolerance limits during germination.

Keywords: Temperature, initial growth of seedlings, biometry

\section{CARACTERIZAÇÃO MORFOMÉTRICA DE SEMENTES E GERMINAÇÃO DE SEIS ESPÉCIES DE LAMIACEAE ENDÊMICAS DO NORDESTE BRASILEIRO}

\section{RESUMO}

O objetivo foi avaliar características morfométricas de sementes, germinação e crescimento inicial de plântulas de seis espécies pertencente à família Lamiaceae, endêmicas da região semiárida do 


\section{MORPHOMETRIC CHARACTERIZATION OF THE SEEDS AND GERMINATION OF SIX ENDEMIC}

LAMIACEAE SPECIES IN NORTHEASTERN BRAZIL

nordeste brasileiro e ainda pouco estudadas. Foram obtidos peso, comprimento, largura e teor de água das sementes de Martianthus leucocephalus, Hyptis suaveolens, H. macrostachys, H. platanifolia, Eplingiella fruticosa e E. cuniloides e comparado o efeito da temperatura na germinação e no crescimento inicial de plântulas das três espécies de Hyptis. As sementes mostraram grande variabilidade e alguns parâmetros podem ser utilizados para fins de identificação de espécies. Sementes de Martianthus leucocephalus apresentaram menores médias para comprimento e largura, enquanto que as maiores médias foram observadas em $H$. suaveolens. As temperaturas entre 25 e $30^{\circ} \mathrm{C}$ foram as que proporcionaram as maiores porcentagens de germinação e obtenção de plântulas vigorosas. Dentre as espécies estudadas, as sementes de $H$. suaveolens apresentaram os maiores limites de tolerância térmica.

Palavras-chave: Temperatura, crescimento inicial de plântulas, biometria

\section{INTRODUCTION}

Lamiaceae comprises about 300 genera and 7.500 species, among which are included several herbs (SOUZA; LORENZI, 2008). Many species of this family are endemic to the semiarid of Brazilian northeast, especially the Hyptis Jaqc genus that includes species rich in essential oil with potential for therapeutic use. Falcão \& Menezes (2003) conducted review on genus and identified about 25 species of Hyptis with pharmacological potential, showing the importance of the genus as a source of bioactive compounds with cytotoxic, antimicrobial, antifungal, anti-inflammatory, anti-HIV and insecticide properties.

Eplingiella fruticosa (Salzm. ex Benth.) Harley \& J.F.B. Pastore (synonymy Hyptis fruticosa Salzm. ex Benth., HARLEY; PASTORE, 2012) is a shrub widely distributed in northeastern Brazil, popularly used against the pain; studies of aqueous extract showed an antinociceptive effect (DE ALMEIDA; ALBUQUERQUE, 2002; SILVA et al., 2006). Martianthus leucocephalus (Mart. ex Benth.) J.F.B. Pastore (synonymy Hyptis leucocephala Mart. ex Benth.) is an aromatic herb decumbent about $20 \mathrm{~cm}$ high, which grows in semiarid of Bahia state, with a production of $0.2 \%$ oil, in average, with antimicrobial activity in leaves AZEVEDO et al., 2016). Widely spread in Brazilian territory, Hyptis suaveolens (L.) Poit. is an annual species, strongly aromatic and height from 0.50 to $1.90 \mathrm{~m}$, reaching up to $3.0 \mathrm{~m}$ depending on the environment. From the leaves one extracts essential oils with 
high levels of cineole (LORENZI; MATOS, 2008). With rare distribution in Bahia state, Eplingiella cuniloides (Epling) Harley \& J.F.B. Pastore (synonymy Hyptis cuniloides Epling, HARLEY; PASTORE, 2012) is a thin shrub, erect, up to $1.5 \mathrm{~m}$ tall, branched at the base, has small gray leaves and occurs in rupestrian fields, forming isolated populations (HARLEY; FRANÇA, 2009). Hyptis macrostachys Benth. is found in semiarid northeastern, popularly known as brave basil or weed mint, its leaves are used in popular medicine against asthma and bronchitis (AGRA et al., 2007). Hyptis platanifolia Mart. ex Benth. is an herbaceous perennial plant with branchy stems, membranous and petiolate leaf and tubular flowers with, both, calyx and corolla white, which grows in the Brazilian northeast (HARLEY; PASTORE, 2012).

Although several studies in the genus Hyptis and other Lamiaceae, have been performed particularly concerning pharmacological aspects, little is known about the appropriate methods of multiplication, conservation and growth. Considering the pharmacological potential of these species, urgent actions related to collecting, characterization and conservation of available germplasm, as well as the development of systems for propagation and cultivation should be taken. These activities would be enabling the inclusion of those important plant genetic resources in a sustainable production system through the establishment of a productive network with native species of the northeastern region.

Besides being the most important input to the multiplication of medicinal and aromatic species, the seeds are the main form of conservation of plant germplasm. Some seed characteristics may be used to identify family and species of the same genus (ABREU et al., 2005), but how the temperature can influence the seed germination and the initial growth of de seedlings of those species should be investigated. Because of the great pharmacological importance of the Lamiaceae species and few papers related to the characterization of seeds and germinability, this study aimed to describing the morphology and evaluating the germination of the six endemic species of a semiarid region in northeastern Brazil. The information generated by this work will contribute to future conservation of seed germplasm, multiplication and sustainable exploitation of these resources.

\section{MATERIAL AND METHODS}

The seeds of the following plant species were collected in Chapada Diamantina, State of Bahia, Brazil: Marianthus leucocephalus (12॰41'0.5"S; 39³5'7.3"W), Eplingiella fruticosa $\left(13^{\circ} 34^{\prime} 14.5^{\prime \prime S}\right.$; $\left.41^{\circ} 10^{\prime} 32.4^{\prime \prime} \mathrm{W}\right), \quad$ E. cuniloides $\left(11^{\circ} 37^{\prime} 40.3^{\prime \prime} \mathrm{S} ; 4^{\circ} 00^{\prime} 1.8^{\prime \prime} \mathrm{W}\right)$, Hyptis suaveolens $\left(12^{\circ} 10^{\prime} 6.7^{\prime \prime} \mathrm{S}\right.$; 
$\left.38^{\circ} 27^{\prime} 14^{\prime \prime} \mathrm{W}\right)$, and $H$. macrostachys $\left(12^{\circ} 35^{\prime} 11.0^{\prime \prime S} ; 40^{\circ} 17^{\prime} 34.5^{\prime \prime} \mathrm{W}\right)$. Only the seeds of $H$. platanifolia were collected in the experimental area of the State University of Feira de Santana, Bahia, Brazil $\left(12^{\circ} 16^{\prime} 00^{\prime \prime} \mathrm{S} ; 38^{\circ} 58^{\prime} 00^{\prime \prime} \mathrm{W}\right)$. After harvesting, the seeds were packed in paper bags and taken to the laboratory; They were manually processed and placed on trays to dry at room temperature and then placed in glass vials containing silica and stored in the refrigerator $\left(5^{\circ} \mathrm{C}\right)$ until starting the essays.

Initially, it was performed the morphological seed characterization (color, texture and apical and base tip shape), followed by mean weight (mg), moisture content (\%) and biometric measures using four repetitions of 100 seeds. For the determination of moisture content, seeds were dried in oven for 17 hours at $107 \pm 3{ }^{\circ} \mathrm{C}$ (ISTA, 2007). For the biometric analyses, length (from apex to base) and width were measured using optical microscope ocular micrometer for E. cuniloides, M. leucocephalus, $H$. macrostachys and H. platanifolia, and stereoscopic microscope ocular micrometer to E. fruticosa and H. suaveolens.

The influence of temperature on seed germination and initial establishment of seedlings was evaluated in three species: $H$. suaveolens, $H$. macrostachys and $H$. platanifolia. These species were chosen due to the availability of seeds. The essay was contucted in incubation chambers B.O.D. (Biochemical Oxygen Demand) with a 12-hour photoperiod (as established by Barroso et al., 2013) at constant temperatures of $20,25,30,35$ and $40^{\circ} \mathrm{C}$. The seeds were placed in Petri dishes covered with two layers of towel paper sterilized and dampened with distilled water (2.5 times the weight of the substrate), using four replicates of 25 seeds per treatment. The number of germinated seeds were daily measured for 30 days, considering the radicle protrusion $(2 \mathrm{~mm})$, the rate of germination $(\mathrm{G} \%)$ and the average time (T, days). Normal seedling (\%) was obtained through monitoring the initial development during the first 10 days after germination, and measuring root and shoot lengths $(n=40)$, using a digital caliper $(\mathrm{mm})$. The experimental design used was completely randomized with four replications. Data were analyzed by ANOVA and differences between means were compared by Tukey test at $5 \%$ of probability using the statistical program Sisvar (FERREIRA, 2011).

\section{RESULTS AND DISCUSSION}

The evaluated seeds of Lamiaceae species showed highly variable morphology. All species presented elongated shape with dorso-ventral flattening (Figure 1). The biometric analysis showed that the length of the seeds ranged from 0.7 and $3 \mathrm{~mm}$; the width between 0.4 and $2 \mathrm{~mm}$; and 100 seeds 
fresh weight ranging from 5 to $190 \mathrm{mg}$. H. suaveolens has bigger seeds showing the largest length and the highest mass while M. leucocephalus has the smallest seeds, almost five times smaller and 38 times lighter than $H$. suaveolens seeds (Figure 1). The high length: width ratio was founded in E. fruticosa seeds (3:1); H. macrostachys, M. leucocephalus and E. cuniloides seeds showed 2:1 ratio, while $H$. plantanifolia and $H$. suaveolens presented 3:2 ratio, corroborating the oblong shape of those seeds (Figures 1E and 1F).

For all species, the apical tips have a rounded shape, except in $H$. suaveolens, which has seeds with a median longitudinal ridge, starting near the hilum and extending to the apex of the seed with retuse boundary (Figure 1). The hilum is located in the proximal end at the base of the seed, whitish color, with ' $\mathrm{V}$ ' aspect on the ventral side, being more pronounced at $H$. macrostachys and linear in $H$. plantanifolia. The coat surface has rugose texture in all species evaluated and the chestnut color is predominant; $M$. leucocephalus seeds have lighter color, shading from caramel to brown and $H$. suaveolens ones have darker color shading from brown to nearly black.

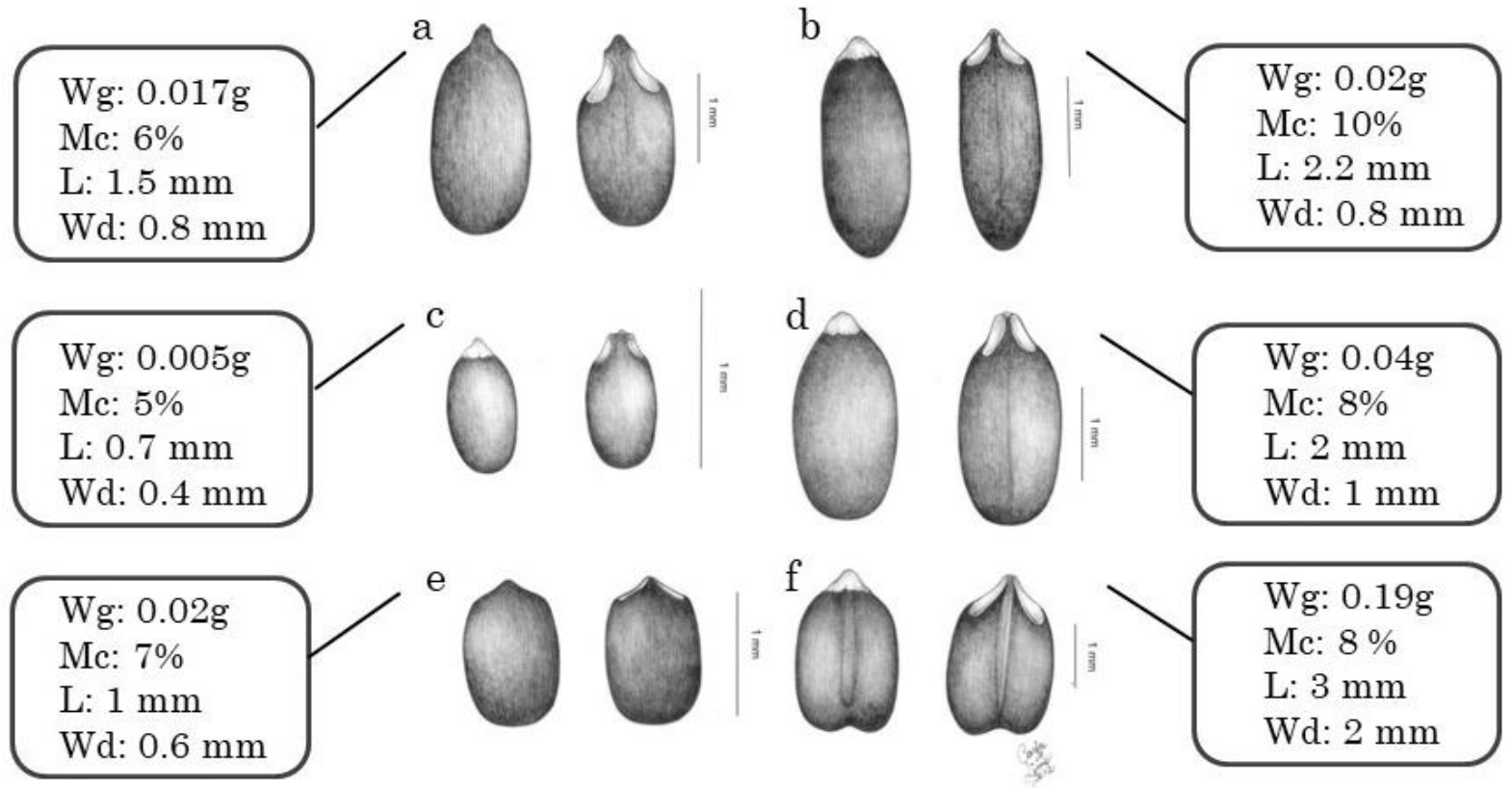

Figure 1. Morphometric characteristics of Hyptis macrostachys (a), Eplingiella fruticosa (b), Marianthus leucocephalus (c), Eplingiella cuniloides (d), Hyptis platanifolia (e) and Hyptis suaveolens (f) seeds. Wg, weigth; Mc, moisture content; L, length; Wd, width. Scale bar = 1 $\mathrm{mm}$. 


\section{MORPHOMETRIC CHARACTERIZATION OF THE SEEDS AND GERMINATION OF SIX ENDEMIC \\ LAMIACEAE SPECIES IN NORTHEASTERN BRAZIL}

Data involving germination and morphology of field-mint (Hyptis cana) showed dark brown seed coat, opaque, rough and whitish hilum (VUADEN et al., 2005), these characteristics being similar to those found in medicinal and aromatic species endemic in the semiarid region of northeastern Brazil.

Seed morphological data can help the understanding about the germination process, the characterization of the vigor, besides allowing the evaluation of seed response exposed to in adequate conditions for germination (MATHEUS; LOPES, 2007). Biometric analysis, including morphology of seeds, can be a tool to detect relations between the genetic and environmental factors, besides being related to the characteristics of dispersal and seedling establishment, and may be used in the botanical identification of genus (CRUZ et al., 2001), providing information also for conservation and exploitation. The size and seed weight may affect the germination success, since there is a relationship between the content of reserves required for the establishment and development of seedlings (ARALDI et al., 2013).

The results obtained in this study showed that the seeds have high morphological variability, with significant differences in length, width and fresh weight; however, these differences did not reflect in seed moisture content. Seeds newly harvested and processed showed a low moisture content ranging from 5 to $10 \%$, which means a high capacity of desiccation tolerance before the time of dispersion (Figure 1). These relatively low moisture content values allow inferences about the orthodox behavior of the species and the ability to keep longevity for longer periods. The high germinability and seed vigor can be maintained for longer periods in seeds with water content around 8-12\% and under ideal conditions of humidity and temperature.

Desiccated seed of all species evaluated in this study had a mucilaginous external layer being visible when they were hydrated getting sticky aspect. Seed mucilage constitutes a diffusion barrier for oxygen, regulating the supply of this gas to the embryo (SUDA; PEREIRA, 1997) as well as an adaptation to dry environment, contributing to retaining water near the seed and forming a water reserve for germination (JOLY et al., 1980). Thus, the presence of mucilage in the seeds newly hydrated suggests that there could be an adaptation of these species to the arid environment, since it allows quick capture and water retention, enabling the seed imbibition culminating with the germination and seedling establishment over the brief rainy season in semiarid region.

The results demonstrate that the germination of $H$. suaveolens, $H$. platanifolia and $H$. macrostachys seeds have a negative quadratic trend and was strongly influenced by the temperature. The germination curves show a temperature range between 20 and $35^{\circ} \mathrm{C}$; the germinability was less 
affected with milder temperatures $\left(20{ }^{\circ} \mathrm{C}\right)$ and one observed that more significant reductions or complete inhibition of germination at higher temperatures $\left(40^{\circ} \mathrm{C}\right)$, especially for the $\mathrm{H}$. platanifolia and H. macrostachys seeds (Figure 2A).
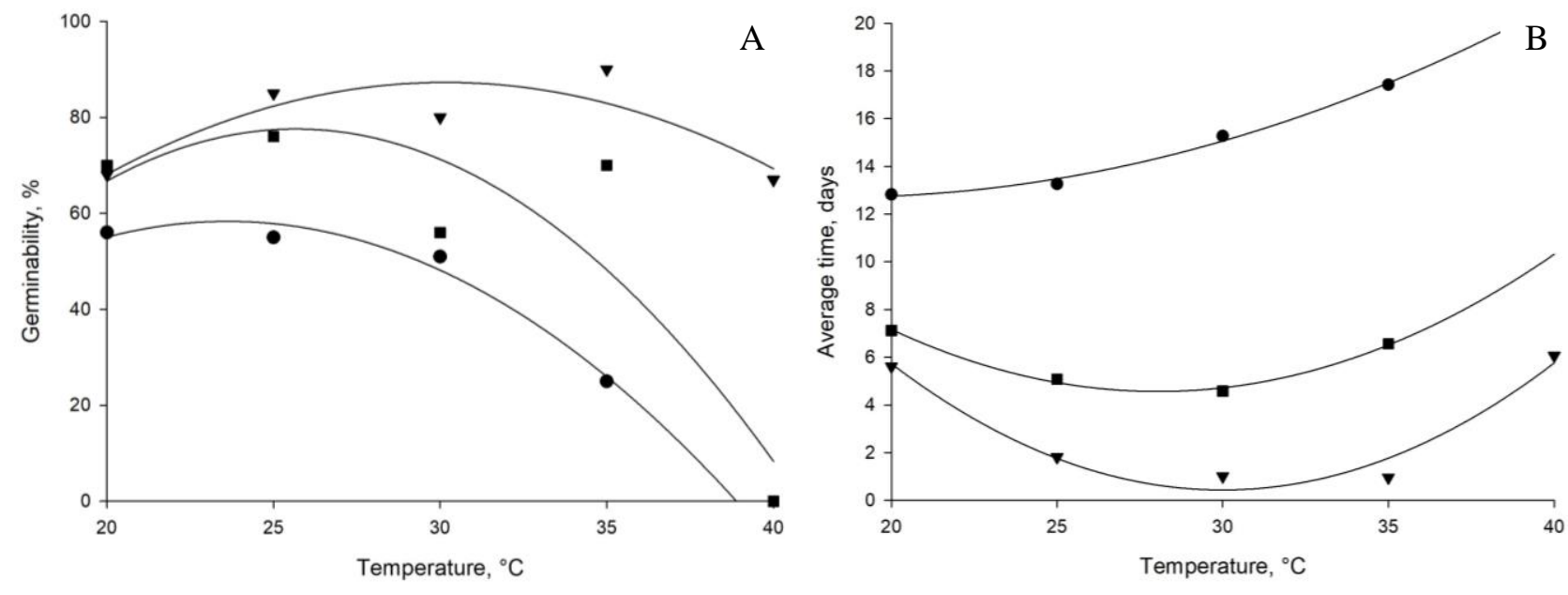

- H. platanifolia $y=-0.2 x^{2}+9.16 x-47.4$

$R^{2}=0.9888$

- H. macrostachys $y=-0.3371 x^{2}+17.309 x-144.57$

- H. suaveolens $y=-0.1857 x^{2}+11.203 x-81.657$

$R^{2}=0.7985$

$R^{2}=0.7241$

$\begin{array}{lll}\text { - H. platanifolia } & Y=0.0107 x^{2}-0.6243 x+18.4045 & R^{2}=0.9923 \\ \text { - } H \text {. macrostachys } & Y=0.0402 x^{2}-2.2546 x+36.179 & R^{2}=0.9898\end{array}$

v. suaveolens $Y=0.0531 x^{2}-3.1837 x+48.176 \quad R^{2}=0.9575$

Figure 2. Germination (A) and average time (B) of Hyptis suaveolens, Hyptis platanifolia and Hyptis macrostachys seeds at different temperatures.

Hyptis suaveolens seeds have better adaptation to high temperatures, with higher germination rates $(80$ to $90 \%)$ at temperatures between 25 and $35^{\circ} \mathrm{C}$, respectively. Seeds of $H$. suaveolens showed even higher speed (Figure 2B) and lower abnormal seedlings at $35^{\circ} \mathrm{C}$ (Table 1). The germination was significantly reduced $(67 \%)$ when the incubation temperature was milder $\left(20^{\circ} \mathrm{C}\right)$ or high $\left(40^{\circ} \mathrm{C}\right)$.

The germinability of $H$. macrostachys seeds achieved 56 to $76 \%$, depending on the temperature tested and did not present differences to average time (5.8 days) of germination except at $40^{\circ} \mathrm{C}$, which germination was zero. The germination of $\mathrm{H}$. platanifolia seeds reached an average of $50 \%$ at $30^{\circ} \mathrm{C}$ and decreased at higher temperatures (Figure 2A). The abnormal seedlings reached 100\% when $H$. macrostachys and $H$. platanifolia seeds were incubated at $35^{\circ} \mathrm{C}$ (Table 1). $H$. platanifolia seeds showed the highest germination at 25 and $30^{\circ} \mathrm{C}$ and the average time was slower (14.7 days). This 
behavior was different in relation to other species (Figure 2B). Sales et al. (2011), working with $H$. marrubioides seeds, found that temperatures of $30^{\circ} \mathrm{C}$ or alternated night/day $20-30^{\circ} \mathrm{C}$ were more favorable for germination, as well as for speed germination. Similar results were found by Vuaden et al. (2004) working with H. cana.

Table 1. Comparison of values for abnormality of seedlings (\%) of Hyptis suaveolens, Hyptis macrostachys and Hyptis platanifolia at different temperatures.

\begin{tabular}{cccc}
\hline $\begin{array}{c}\text { Temperature } \\
\left({ }^{\circ} \mathbf{C}\right)\end{array}$ & H. suaveolens & H. macrostachys & H. platanifolia \\
\hline $\mathbf{2 0}$ & $15 \mathrm{~b}$ & $0 \mathrm{a}$ & $12.5 \mathrm{a}$ \\
$\mathbf{2 5}$ & $0 \mathrm{a}$ & $0 \mathrm{a}$ & $15.0 \mathrm{a}$ \\
$\mathbf{3 0}$ & $0 \mathrm{a}$ & $5 \mathrm{~b}$ & $12.5 \mathrm{a}$ \\
$\mathbf{3 5}$ & $22.5 \mathrm{~b}$ & $100 \mathrm{c}$ & $100 \mathrm{~b}$ \\
$\mathbf{4 0}$ & $92.5 \mathrm{c}$ & - & - \\
\hline
\end{tabular}

Means followed by the same letter in the column do not differ by Tukey test at $5 \%$.

-: not detected

The establishment of temperature or the thermal amplitude that promotes seed germination takes into consideration some kinetic factors including the speed germination. In the present work, it was found that temperature that provided the smaller average time is the same in which succeed the highest rates of germination in these three evaluated Hyptis species (Figure 2). According to Ferreira and Borghetti (2004) this is a good index for evaluating the speed distribution of a species in an environment, because a prompt germination can be a strategy for the quick establishment, taking advantage of favorable environmental conditions, as opening glades or rainfall. The thermal amplitude that promotes seed germination of Hyptis suaveolens and the strategy of quick establishment in the environment could explain the success of this species considered an invasive with ruderal habit (MAIA et al., 2008).

Concerning the seed vigor, it was observed that $H$. suaveolens had the largest seeds (Figure 1) and produced larger seedlings; however, the average length of the seedlings was influenced by temperature of incubation (Table 2). The highest investment in seedlings assimilates were observed in those temperatures that favored the germination and have positively influenced the speed of the process. During early development, for all species studied, the seedlings roots had higher growth when compared to the shoot. We noticed also the root/shoot length rate of the seedlings was always high and positive, except at highest temperatures $\left(35\right.$ and $\left.40^{\circ} \mathrm{C}\right)$, in which the root growth stopped or germination was completely inhibited, as observed in H. macrostachys and H. platanifolia. 
Considering the differences between species studied, in relation to seed biometric parameters and initial seedling growth, it is suggested the increase in the number of species to test correlations between these variables, in order to enhance knowledge about the physiology of germination allowing further conservation work of Lamiaceae seeds.

Table 2. Comparison of values for root length (RL, mm), shoot length (SL, mm) and root: shoot length ratio (RL:SL) of Hyptis suaveolens, Hyptis macrostachys and Hyptis platanifolia during initial growth of seedlings at different temperatures.

\begin{tabular}{|c|c|c|c|c|c|c|c|c|c|}
\hline \multirow{2}{*}{$\begin{array}{c}\text { Temperature } \\
\left({ }^{\circ} \mathrm{C}\right)\end{array}$} & \multicolumn{3}{|c|}{ H. suaveolens } & \multicolumn{3}{|c|}{ H. macrostachys } & \multicolumn{3}{|c|}{ H. platanifolia } \\
\hline & RL & SL & RL:SL & $\mathrm{RL}$ & SL & RL:SL & RL & SL & RL:SL \\
\hline 20 & $17.4 \mathrm{~cd}$ & $11.5 \mathrm{ab}$ & $1.5 \mathrm{a}$ & $5.6 \mathrm{a}$ & $2.6 \mathrm{~b}$ & $2.1 \mathrm{~b}$ & $7.3 \mathrm{~b}$ & $4.2 \mathrm{~b}$ & $1.7 \mathrm{a}$ \\
\hline 25 & $23.8 \mathrm{c}$ & $8.5 \mathrm{c}$ & $2.8 \mathrm{~b}$ & $4.8 \mathrm{a}$ & $3.0 \mathrm{ab}$ & $1.6 \mathrm{ab}$ & $16.3 \mathrm{a}$ & $3.9 \mathrm{~b}$ & $4.2 \mathrm{c}$ \\
\hline 30 & $33.2 \mathrm{~b}$ & $13.2 \mathrm{a}$ & $2.5 \mathrm{~b}$ & $5.2 \mathrm{a}$ & $3.5 \mathrm{a}$ & $1.5 \mathrm{a}$ & $18.0 \mathrm{a}$ & $6.3 \mathrm{a}$ & $2.9 \mathrm{~b}$ \\
\hline 35 & $47.0 \mathrm{a}$ & $10.7 \mathrm{~b}$ & $4.4 \mathrm{c}$ & - & - & - & - & - & - \\
\hline 40 & $14.6 \mathrm{~d}$ & $6.2 \mathrm{~d}$ & $2.3 \mathrm{~b}$ & - & - & - & - & - & - \\
\hline
\end{tabular}

Means followed by the same letter in the column do not differ by Tukey test at 5\%. -: not detected.

\section{CONCLUSION}

There is great variation between the seeds of different Lamiaceae species. The seeds size and weight influences the seedlings length; temperatures of 25 and $30^{\circ} \mathrm{C}$ provide the highest germination rate, speed germination and more vigorous seedling establishment; seeds of Hyptis suaveolens support a wider range of temperatures during germination.

\section{ACKNOWLEDGEMENTS}

To "Conselho Nacional de Desenvolvimento Científico e Tecnológico" (CNPq, National Council for Scientific and Technological Development) and "Fundação de Amparo à Pesquisa do Estado da Bahia" for the financial support

\section{REFERENCES}

ABREU, D. C. A.; KUNIYOSHI, Y. S.; MEDEIROS, A. C. S.; NOGUEIRA, A. C. 2005. Caracterização morfológica de frutos e sementes de cataia (Drimys brasiliensis Miers.Winteraceae). Revista Brasileira de Sementes, Londrina, v. 27, n. 2, p. 67-74.

AGRA, M. F.; FREITAS, P. F.; BARBOSA-FILHO, J. M. 2007. Synopsis of the plants known as medicinal and poisonous in Northeast of Brazil. Revista Brasileira de Farmacognosia, Curitiba, v. 17, n.1, p. 114-140. 
ARALDI, R.; VELINI, E. D.; GOMES, G. L. G. C.; CARBONARI, C. A.; ALVES, E.; TRINDADE, M. L. B. 2013. Variação do tamanho de sementes de plantas daninhas e sua influência nos padrões de emergência das plântulas. Planta Daninha, Viçosa, v. 31, n.1, p. 117-126.

AZEVEDO, B. O; OLIVEIRA, L. M; LUCCHESE, A. M.; SILVA, D. J; LEDO, C. A. S.; NASCIMENTO, M. N. 2016. Growth and essential oil production by Martianthus leucocephalus grown under the edaphoclimatic conditions of Feira de Santana, Bahia, Brazil. Ciência Rural. Santa Maria , v. 46, n. 4, p. 593-598.

BARROSO, N. S.; SOUZA, C. L. M.; PELACANI, C.R.; OLIVEIRA, L. M. 2013. Influência do fotoperíodo na germinação de sementes de espécies do gênero Hyptis (Lamiaceae) Magistra, Cruz das Almas-BA, v. 25, n. 358, I RGVNE, p. 358- 359.

CRUZ, E. D.; MARTINS, F. O.; CARVALHO, J. E. U. 2001. Biometria de frutos e sementes e germinação de jatobá-curuba (Hymenaea intermedia Ducke, Leguminosae - Caesalpinioideae). Revista Brasileira de Botânica, São Paulo, v. 24, n. 2, p. 161-165.

DE ALMEIDA, C. F. C. B. R.; ALBUQUERQUE, U. P. 2002. Check-list of the Family Lamiaceae in Pernambuco, Brazil. Brazilian Archives of Biology and Technology, Curitiba, v. 45, n. 3, p. 343353.

FALCÃO, D. Q.; MENEZES, F. S. 2003. Revisão etnofarmacológica, farmacológica e química do gênero Hyptis. Revista Brasileira de Farmacognosia, Curitiba, v. 84, n. 3, p. 69-74.

FERREIRA, A. G.; BORGHETTI, F. 2004. Germinação: do básico ao aplicado. Porto Alegre:Artmed. 323 p.

FERREIRA, D. F. Sisvar: a computer statistic alanalysis system. Ciência e Agrotecnologia, Lavras, v. 35, n.6, p.1039-1042, 2011.

HARLEY, R.M.; FRANÇA, F. 2009. Verbenaceae. In: GIULIETTI, A. M.; RAPINI, A.; ANDRADE, M. J. G.; QUEIROZ, L. P.; SILVA, J. M. C. (Orgs.). Plantas Raras do Brasil. Belo Horizonte: Conservação Internacional - Brasil \& Universidade Estadual de Feira de Santana. p. 23-35.

HARLEY, R. M.; PASTORE, J. F. B. 2012. A generic revision and new combinations in the Hyptidinae (Lamiaceae), based on molecular and morphological evidence. Phytotaxa, Auckland, v. 58, p.1-55.

ISTA, 2007. International Rules for Seed Testing Association. Bassersdorf, Switzerland. p. 248

JOLY, C. A.; FELIPPE, G. M.; DIETRICH, S. M. C.; CAMPOS-TAKAKI, G. M. 1980. Physiology of germination and seed gel analysis in two populations of Magonia pubescens. St. Hil. Revista Brasileira de Botânica, São Paulo, v.3, n. 1, p. 1-9.

LORENZI, H.; MATOS, F. A. 2008. Plantas Medicinais no Brasil: nativas e exóticas. Nova Odessa, Ed. Plantarum. p. 544.

MAIA, S. S. S.; PINTO, J. E. B. P.; SILVA, F. N.; OLIVEIRA, C. 2008. Enraizamento de Hyptis suaveolens (L.) Poit. (Lamiaceae) em função da posição da estaca no ramo. Revista Brasileira de Ciências Agrárias, Recife, v. 3, n. 4, p. 317-320.

MATHEUS, M. T.; LOPES, J. C. 2007. Morfologia de frutos, sementes e plântulas e germinação de sementes de Erythrina variegata L. Revista Brasileira de Sementes, Londrina, v. 29, n. 3, p. 8-15.

SALES, J. F; PINTO, J. E. B. F; OLIVEIRA, J. A.; BOTREL, P. P.; SILVA, F. G.; CORREA, R. M. 2011. The germination of bush mint (Hyptis marrubioides EPL.) seeds as a function of harvest stage, light, temperature and duration of storage. Acta Scientiarum Agronomy, Maringá, v. 33, n. 4, p. 709-713.

SILVA, A. B. L.; DIAS, K. S.; MARQUES, M. S.; MENEZES, I. A. C.; SANTOS, T. C.; MELLO, C. M.; LISBOA, A. C. C. D.; CAVALCANTI, S. C. H.; MARÇAL, R. M.; ANTONIOLLI, A. R. 2006. Avaliação do efeito antinociceptivo e da toxicidade aguda do extrato aquoso da Hyptis 
fruticosa Salmz. ex Benth. Revista Brasileira de Farmacognosia, Curitiba, v. 16, n. 4, p. 475479.

SOUZA, V. C.; LORENZI, H. 2008. Botânica Sistemática. Guia ilustrado para identificação das famílias de Angiospermas da Flora Brasileira, baseado em APG II. Ed. 2. Instituto Plantarum de Estudos da Flora Ltda, Nova Odessa. p.703

SUDA, C. N. K.; PEREIRA, M. F. D. A. 1997. Sensibilidade à luz de sementes de Euphorbia heterophylla L. durante a germinação. Revista Brasileira de Fisiologia Vegetal, Campinas, v. 9, n. 1, p. 55-64.

VUADEN, E. R.; AlBuQuerque, M. C. F.; COElHO, M. F. B.; MENDONÇA, E. A. F. 2005. Germinação e morfologia de sementes e de plântulas de hortelã-docampo Hyptis cana Pohl. (Lamiaceae). Revista Brasileira de Sementes, Londrina, v. 27, n. 2, p. 1-5.

VUADEN, E. R.; ALBUQUERQUE, M. C. F.; GUIMARÃES, S. C.; COELHO, M. F. B. 2004. Efeito da temperatura sobre a germinação de sementes de Hyptis cana Pohl. provenientes de diferentes ambientes. Revista Brasileira de Plantas Medicinais, Botucatu, v. 7, n. 1, p. 92-97.

Received in: December 01, 2016 Accepted in: November 16, 2017 